\title{
Translation and Semantic Issues (A Translation Study of The Metaphor Text)
}

\author{
Endang Purwaningsih \\ Universitas Sebelas Maret \\ Surakarta, Indonesia \\ e_purwaningsih@staff.gunadarma.ac.id \\ M.R. Nababan \\ Universitas Sebelas Maret \\ Surakarta, Indonesia \\ amantaradja@gmail.com
}

\author{
Djatmika \\ Universitas Sebelas Maret \\ Surakarta, Indonesia \\ djatmika@staff.uns.ac.id \\ Agus Hari Wibowo \\ Universitas Sebelas Maret \\ Surakarta, Indonesia \\ agushari67@staff.uns.ac.id
}

\begin{abstract}
The translation process is concerned about transferring or rendering a text from source language into target language. The process involves not only the language but also regards to semantic aspects referred to by the source language that is translated by translator and read by reader. Our paper studies the process of translation and semantic issues, particularly the translation of metaphors on the translation product translated by two different translators. The translated source text is speech text. From this research, we looked at the issues faced by the translators when working on the translation of metaphor from the speech text. The translators have problems to find the appropriate equivalents in order to make the reader easy to understand the translated text.. The results showed that at first, the semantic issues discussed in here are about meaning of the words in the speech text. However, the results showed that the issues of semantics, particularly about metaphor in the speech text, are not only a mere different meaning of the words, but also concerns context, knowledge, and patterns of thought that is different between the author of the speech text and the both translators.
\end{abstract}

Keywords: translation, technique, cognitive semantics, speech text

\section{INTRODUCTION}

Metaphor is commonly used in daily communication to introduce the new concept or a more precise meaning. Metaphorexists in communication due to it is able to pronounce the short and dense meaning, along with poetic effects. That is why in some speech often use metaphor for a special reason or for giving a poetic effect. Metaphor in a speech is often used to pronounce a special message, but mostly the audiences do not understand. Furthermore, that metaphor has to be interpreted into certain target languages. This situation often happens in interpreting the metaphor of speech.

West and Turner (2013) stated one of the strategies to get the effective persuasion and speech is by using metaphor. The use of metaphor by pronouncing the strong parable can help the audiences imagining the scenes depicted. The speechwriter is able to define various terminologies by considering the similar idea to his/ her own thoughts. So, he/ she is able to find the chain to reconcile his/ her thoughts to the public's to avoid losing interest and create a chance to persuade them (West and Turner, 2004). To understand more about the idea pronounced by the writer cognitively in one language, as said by Lakoff (1993) by means of the theory of conceptual metaphor, isn't easy, even less in cross-language.

Beekman and Callow (1974) explained that metaphor contains three parts, which are (a) The topic, which is an object or thing that is discussed; (b) The image, which is a metaphorical part of the figure of speech that is used to describe the topic in order of comparison; (c) The point of resemblance, which is a part that shows the similarities between the topic and image. Those three parts aren't always mentioned explicitly. Sometimes, one of them, which is the topic, a part of the image, or the point of resemblance is implicit; as seen in the example. He is also Baldwin's legal eagle'. The metaphors topic above is he, and the image is an eagle. But the point of resemblance isn't mentioned explicitly whether it is he or eagle. To understand this point of resemblance, it is needed deeper knowledge about the context of a place where that metaphorbelongs, the comprehension to the meaning of eagle symbol in society and other implicit elements.

Ulman (1962: 212-213) defined metaphor as a simple comparison using intuition and concrete signs. Ulman also stated metaphor as the similarity of sense and a creative force in language. Richards (in Ulman, 1962) named those elements as tenor and vehicle. While Black (in Ortony, 1979) named them as focus and frame; Sapir (in Ortony, 1979) named them as continuous term and discontinuous term; Ulman (1962) 
named them as intuition and concrete sign; while Konvesces (2002: 4) named them as conceptual realm (A) and conceptual realm $(\mathrm{B})$.

\begin{abstract}
Newmark (1988: 104) defined a metaphor as ".... any figurative expression: the transferred sense of the physical word....; the personification of an abstraction ....; the application of a word or collocation to what it does not literally denote, i.e to describe one thing in term of another".
\end{abstract}

The realization of metaphor can be one word or word combinations, starting from the collocation to the textual level. Metaphor by Newmark (1988) is described by three terminologies: (1) image, which is an image of something through metaphor universally, culturally or individually, 2). The object, which is something that will be described by metaphor and 3). Sense is a literal meaning of a word used as metaphor, which is resemblance or the meeting point of object and image. Furthermore, Newmark has another opinion that metaphor has two functions: 1). Referential function or denotative (cognitive), which is to describe the process of mental, concept, human, object, quality or comprehensive and dense act than using literal language, 2). Pragmatic function (aesthetic) or connotative, which is to utter the meaning, attract readers, clarify something, please the readers, or give surprises to the readers.

Talking about the translation that emphasizes on the resemblance of the meaning, Nida \&Taber (1982:4) said that 'anything that can be said in one language can be said in another unless the form is an essential element of the message'. If the source text (ST) is made by emphasizing the form of the text for certain purposes, such as for entertaining, so when those texts are interpreted, they are no longer something to be maintained. Likewise when the translator doesn't aim to synchronize the meaning of the target text to the source text, so it doesn't produce translation text but adaption text. Nida (2001:3) added: "What clients need and generally demand is first and foremost accuracy. If a translated text can also be easy to read, this is indeed a plus factor and if it can be culturally appropriate the translation is obviously a success'.

To solve the problem of metaphor translation in a matter of translation technique, Newmark (1982:84-86) suggested some procedures of metaphor translation:

1. Reproducing the same image in the $T L$ "metaphor in ST is translated as a metaphor in TT with the same image (SD);

2. Replacing the image in the SL with a standard TL image which does not clash with the TL culture

3. Translation of metaphor by simile, retaining the image metaphor
4. Translation of metaphor (or simile) by simile plus sense (or occasionally a metaphor plus sense 'metaphor or simile

5. Converting metaphor to sense

6. Deletion, if the metaphor is redundant

7. Using the same metaphor combined with sense, in order to enforce the image

This research aims to analyze the result of metaphor translation in a speech. By this research, it is expected to find the result of metaphor translation that produces the meaning resemblance so the result will be a good translation.

\section{THEORETICAL REVIEW}

Lakoff and Johnson (1980:3) looked at metaphor not only a language phenomenon but also engaging the thought and human behavior: "... metaphor is pervasive in everyday life, not just in language but in thought and action." The essence of metaphor, according to them, is how we understand and experience something (concept) through others ("the essence of metaphor is understanding and experiencing one kind of thing in terms of another"). By another word, metaphor is a method to understand one realm of experience (SD) through other easier or popular realm of experience (TD). According to those frameworks, it can be said that the way someone thinks, experiences, and does something in his/her daily life basically is an application of metaphor. So it can be concluded that the human conceptual system is metaphorical (Lakoff \& Johnson 1980:3).

The framework of cognitive metaphor is also named by Lee (2001:6) “... a metaphor is essentially a device that involves conceptualising one domain of experience in terms of another. Thus, for any given metaphor, one can identify a source domain and a target domain". As metaphor is a device that can be used by the writer to pronounce a cognitive experience conceptually (ST) through another experience (TT), in another word, metaphor is basically an ontological relation between $\mathrm{ST}$ and $\mathrm{TT}$.

To examine the translation in metaphor, it is needed to explain about metaphor. Metaphor can be classified according to the semantic field. The semantic field is a certain part of the lexicon that is defined as a terminology or general concept. In metaphor creation, the language depends on the socio-cultural environment (Halay, 1980: 139). It happens due to the human perception occurs in the whole environment. The human perception contains these: the metaphor of circumstances (being), cosmos, energy, substance, terrestrial, object, living, animate, and human(Halay, 1980: 159, Lunsford 1980: 139). Ullman (1962) divided metaphor based on four categories, such as (1) anthropogenicmetaphor, (2) animal metaphor, (3) from concrete to abstract, and (4) synesthetic metaphor. 
To understand metaphor, there are two main problems: 1) How to differentiate metaphorical language (non-literal) and non-metaphorical (literal), 2) Decide various forms of language that can be used in metaphorical expression (Henderson, 1994:344). Aristoteles emphasized on the first problem, which was the differences of metaphorical and nonmetaphorical meaning, while the classic approach to the metaphor (post-Aristoteles period) emphasized to the second problem, which was the structural and grammatical aspect of the metaphorical expressions. Thus, the modern approach to the metaphor emphasizes on the metaphorical language (nonliteral).

The most consistent description of metaphor is given in the classic literature and experimental, in which the metaphor is the representative of two semantic fields. Both can be defined differently and have a different meaning as well. Richards, as quoted by Wilcox (2000), is an expert of metaphor theory who for the first time invented two concepts of tenor and vehicle that contain and operate simultaneously in metaphor. Kittay (1987:16) gives her second framework: "the vehicle is the idea conveyed by the literal meaning of the words used metaphorically. The tenor is the idea conveyed by the vehicle."

Black (1962:39) used a different terminology for metaphor units, which are a frame (contains phrase, sentence, or paragraph) and focus, which is the lexical unsure used metaphorically. The grammatical meaning of the sentence is centralized on the word focus. Kittay (1987:24) described frame as ".. the minimal unit which establishes the incongruity". More implicit a frame, wider the metaphor interpretation will be. Black uses the principal subject for tenor and subsidiary subject for the vehicle. Although Kittay (1987:26) uses the definition of the vehicleas suggested by Black, she chooses the terminology of transport and uses the topic for tenor which is what's been discussed. Thus, the metaphor meaning will be expanded if there is the meaning transfer from the meaning field of the vehicleon the conceptual domain of topic.

The translation technique used in this research is a result from the synthesis of some metaphor translation techniques and the translation technique that is suggested by Newmark (1982), Larson (1984), Toury (1995), Chestermen (1997) and Molina \&Albir (2005). This research uses the definition of translation technique suggested by Molina \&Albir (2005), which is the translation has five characteristics:

1. The translation technique influences the translation result.

2. The technique is classified by the comparison on SL text.

3. The technique is at the micro level.
4. The technique is unrelated but based on certain context, and

5. The functional technique.

According to five criteria suggested by Molina and Albir (2005), the translation technique starts from identifying the translation problem by the translator to decide the solution to solve or the translator's effort about why the solution cannot be solved.

\section{RESEARCH METHOD}

This research uses the descriptive qualitative method. The descriptive qualitative research uses an interdisciplinary approach to understand certain phenomenon and context. This research uses the qualitative method because the data is translated text of a speech from the source language to the target language. In the qualitative research, the reality is naturally plural, heterogeneous and holistic, and it isn't singular as the quantitative research (Lincoln and Cuba, 1985). It can be concluded that the reality has various interpretations.

This research is a qualitative research as it aims to understand the phenomenon of metaphor forms and types used by women leaders to deliver a public speech. And it analyzes the result of metaphor translation by two different gender translators that will create the differences of meaning and purpose of the metaphor. The analysis technique in this research uses qualitative research. In this research, the writer has read four speeches in the source language and translated speeches text that are the objects of this research. This research is a research-oriented to the product due to this research focuses on translation and doesn't explain how the translation is done by the translator. The products are the result of translated speech text given by a female rector while giving the welcome public speech. In this research, the data comes from the metaphor exists in the speech text of female rector's inauguration in the University in America. The data is translated into Bahasa Indonesia by two different gender translators.

\section{RESUlT AND DISCUSSION}

These are the examples of the result of translated text by the male translator (Bahasa Sasaran 1/Bsa1) and female translator (Bahasa Sasaran 2/Bsa2). The selected translation results are the sentences that contain metaphor.

(The speech text of female President of University/ MIT President Susan Hockfield (Massachusetts Institute of Technology) May 6, 2005)

Example 1:

BSu_(Bahasa Sumber/Source Language):

Thank you! To all of you gathered here in the great embrace of Killian Court-to all the students, faculty, alumni, staff, members of the Corporation and friends. 
Bsa 1 (Male translator)

Terimakasih! Untuk_semua_Anda yang berkumpul di sini dalam_pelukan_besar_dari_Pengadilan Killian Court- untuk semua_mahasiswa, fakultas, alumni, staff, para anggota Korporasidan temale-temale.

Bsa 2 (Female translator)

Terimakasih! Kepada_Anda_semua yang hadir di tempat_ini dalam_ruangan_Killian Court - kepada_semua_mahasiswa, dosen, alumni, staf, anggota_Korporasi_dan_rekan-rekan.

According to the analysis result on the source data, vehicle or word of metaphor in the BSu sentence is embrace that has tenor or metamorphosis meaning of a space and background of this metaphor word is by inserting something into the certain part. This metaphor can be classified into metaphor ontology (metaphor personification) due to the word embrace as a vehicle or source is an action or activity that makes Killain Court as the target of metaphor just like a human. After being translated into Bahasa Indonesia (Bsa), the metaphor word embrace has differences and similarities.

\section{Differences:}

According to above explanation, the differences are in the vehicle of the metaphor of embrace that is non-metaphorically translated by two translators, which are female and male translators. Technically, the word embrace is translated as pelukan/ hug and uses literal translation technique by a male translator due to the translation is out of context and word-forword. By the female translator, the metaphor word is translated into non-metaphorical, which is the word ruangan/ room by using variation translation technique, due to the metaphor word of $\mathrm{BSu}$ is transferred into a non-metaphorical word that has similar place or space with the tenor on $\mathrm{BSu}$. Another difference is the female translator applies the reduction translation technique where the word great is dismissed on Bsa, while the male translator keeps that word and applies the common-matching technique.

\section{Similarities:}

The sentence of BSU is translated using the common matching technique by both translators on the sentence to all of you gathered here in... As this sentence has had the synonym on Bsa and can be understood by the Bsa speaker.

\section{Example 2:}

BSu:

Thank you for your welcome to the great global family of MIT.

Bsa (1):

Terimakasih_untuk_penerimaan_Anda_untuk_keluarga global besar_dari MIT.

Bsa2:

Terimakasih_atas_penyambutan_Anda_untuk_keluarga_besar MIT.

\section{Analysis:}

On the description of those two data above, the word family on $\mathrm{BSu}$ is metaphor diversified as a structural metaphor. Structurally, family as the vehicle has the metaphor meaning as a group of people of the institution, in this case,MIT is an institution that is the target field of the metaphor. Each member of this institution doesn't have blood relation literally but they have values and close relationship as a family, which is why the word family is the target field used. Next will be the differences and similarities of metaphor on $\mathrm{BSu}$ and Bsa to discuss below:

\section{Differences:}

At one look, it can be understood that two vehicles from $\mathrm{BSu}$ and Bsa are different due to both of them are coming from a different language. Another difference is on the compensation technique used by the female translator to translate the word global, this word isn't translated into Bsa.

\section{Similarities:}

The similarities are on the metaphor tenor of Bsa and both metaphor translation, and on the translation of family into keluarga by both of the translators. It is due to the usage of common-matching technique while transferring the metaphor from BSu to Bsa.

Example 3:

BSu:

... thank you for your welcome to the great global family of MIT. (2) (Speech D, ph 1)

Bsa (1)

Terima kasih untuk penerimaan Anda untuk keluarga global besar dari MIT. (2)

Bsa (2)

.... terima kasih atas penyambutan Anda untuk keluarga besar MIT. (1)

Analysis:

The metaphor of global is the source field for the target field of MIT (Institution), data 3 belongs to the category of structural metaphor as an institution has members come from various origins. This metaphor has the differences and similarities as follow:

\section{Differences:}

The vehicle of $\mathrm{BSu}$ and Bsa is different due to both of them come from two different language, on the two text of Bsa can be found that the metaphor of global is nonmetaphorical translated by the male translator while the female translator translates it in a metaphor. Both male and female translators translate the sentence on data 3 in a different technique, the male translator uses commonmatching and literal technique while the female translator uses common-matching and compensation. The metaphor word of global is translated literally by the male translator while the female translator compensates the metaphor into the word 
besar/ big due to if it is translated literally there are possible to create the style influences in Bsa.

\section{Similarities:}

There is the same tenor from BSu and Bsa.

\section{Example 4:}

BSu:

The MIT family is enlarged today.... (Speech D, ph 2).

Bsa 1:

Keluarga MIT diperbesar_hari_ini...

Bsa 2:

Hari ini_keluarga MIT diperbesar...

According to $\mathrm{BSu}$, it can be explained that the word forces, the form of metaphor are categorized into word class of noun, abstract and inanimate, as well as on the word kekuatan-kekuatan/ powers (Bsa1 and Bsa2) are categorized in the same form of metaphor as BSu. The word 'forces' and 'powers' are included in the form of nomina, categorized as an abstract or hidden metaphor, and inanimate. There are no differences between BSu becomes Bsa (1) and (2) in the type of metaphor, the form of lexical, word class, and morphological aspect.

According to above analyze, it can be explained that the metaphor translation technique on the speech text is an important thing to be investigated since it covers various language aspects. To find the right type and technique of translation in metaphor, the researcher uses two approaches, which are the metaphor and translation approach.

BSu: To all of you gathered here in the great embrace of Killian Court... (Speech D, ph 1)

BS1: Untuk_semua_Anda yang berkumpul di sini_dalam pelukan_besar_dari_Pengadilan Killian Court.

BS2: Kepada_Anda_semua yang hadir di tempat_ini dalam_ruangan_Killian Court.

\section{Analysis:}

According to above list, vehicle or word that becomes a metaphor in the sentence BSuis embrace that has a tenor or metaphorical meaning in the field of room and background of this metaphor word is by inserting something into the certain part. This metaphor can be classified into ontological metaphor (personification metaphor) due to the word embrace as vehicle or source is an action or activity that mentions Killain Court as the target of metaphor the metaphor word embrace has differences and similarities.

\section{Differences:}

According to above explanation, the differences are in the vehicle of the metaphor of embrace that is non-metaphorically translated by two translators, which are female and male translators. Technically, the word embrace is translated as pelukan/ hug and uses literal translation technique by a male translator due to the translation is out of context and word-for- word. By the female translator, the metaphor word is translated into non-metaphorical, which is the word ruangan/ room by using variation translation technique, due to the metaphor word of $\mathrm{BSu}$ is transferred into a non-metaphorical word that has similar place or space with the tenor on $\mathrm{BSu}$. Another difference is the female translator applies the reduction translation technique where the word great is dismissed on Bsa, while the male translator keeps that word and applies the common-matching technique.

\section{Similarities:}

The sentence of BSU is translated using the common matching technique by both translators on the sentence to all of you gathered here in... as this sentence has had the synonym on Bsa and can be understood by the Bsa speaker.

\section{BSu:}

Thank you for your welcome to the great global familyof MIT. Bsa (1):

Terimakasih_untuk_penerimaan_Anda_untuk_keluarga_global besar_dari MIT.

Bsa2:

Terimakasih_atas_penyambutan_Anda_untuk_keluarga_besar MIT.

\section{Analysis:}

On the description of those data 2 above, the word family on BSu is metaphor diversified as a structural metaphor. Structurally, family as the vehicle has the metaphor meaning as a group of people of the institution, in this case,MIT is an institution that is the target field of the metaphor. Each member of this institution doesn't have blood relation literally but they have values and close relationship as a family, which is why the word family is the target field used. Next will be the differences and similarities of metaphor on BSu and Bsa to discuss below:

\section{Differences:}

At one look, it can be understood that two vehicles from $\mathrm{BSu}$ and Bsa are different due to both of them are coming from a different language. Another difference is on the compensation technique used by the female translator to translate the word global, this word isn't translated into Bsa.

\section{Similarities:}

The similarities are on the metaphor tenor of Bsa and both metaphor translation, and on the translation of family into keluarga by both of the translators. It is due to the usage of common-matching technique while transferring the metaphor from BSu to Bsa.

\section{Analysis:}

BSu: ...thank you for your welcome to the great global family of MIT. (2) (Speech D, ph 1)

BS1: ... terimakasih_untuk_penerimaan_Anda_untuk_keluarga global besar_dari MIT. (2) 
BS2: ....terimakasih_atas_penyambutan_Anda_untuk_keluarga besar_MIT (1)

The metaphor of global is Metaphor of global is the source field for the target field of MIT (Institution), data 3 belongs to the category of structural metaphor as an institution has members come from various origins. This metaphor has the differences and similarities as follow:

\section{Differences:}

The vehicle of BSu and Bsa is different due to both of them come from two different language, on the two text of Bsa can be found that the metaphor of global is nonmetaphorical translated by the male translator while the female translator translates it in a metaphor. Both male and female translators translate the sentence on data 3 in a different technique, the male translator uses commonmatching and literal technique while the female translator uses common-matching and compensation. The metaphor word of global is translated literally by the male translator while the female translator compensates the metaphor into the word besar/ big due to if it is translated literally there are possible to create the style influences in Bsa.

\section{Similarities:}

There are similarities of tenor from BSu and Bsa.

\section{Analysis:}

BSu: The MIT family is enlarged today... (Speech D, ph 2)

Bsa1: Keluarga MIT diperbesar_hari ini...

Bsa2: Hari ini_keluarga MIT diperbesar...

The phrase of MIT family as the target field of metaphor enlarged as conceptual can be understood as a member of an institution that can be developed or enlarged (for its number or quality). The word enlarged literally can refer to the magnification (the size of thing) but structurally the metaphor here is understood as an activity to honor the institution. As MIT family can be understood according to the structure of enlarged as the vehicle from metaphor, so this metaphor is a type of structural metaphor.

\section{Differences:}

As well as the previous data, this metaphor also has the different vehicle between its BSu and Bsa. Another difference is in the background of BSu metaphor and Bsa background.

\section{Similarities:}

The aspects of vehicle and tenor on $\mathrm{BSu}$ and Bsa have similarities, besides the translation technique used by both translators are same, which is the common-matching technique as the translators transfer the messages of BSu into the common synonym of Bsa that are understood by the Bsa speaker.

\section{Analysis:}

BSu: MIT has a habit of holding onto its presidents after they leave office. (Speech D, ph 5)

Bsa1: MIT punya_kebiasaan_berpegang_kepada_pada_rektornya_setelah_mereka_meninggalkan jabatan_mereka.

Bsa2: MIT mempunyai_kebiasaan_untuk_terus_menjalin hubungan_erat_dengan_presidennya_setelah_mereka menyelesaikan_tugas_mereka.

Data 5 is categorized as an ontological metaphor (personification) due to holding onto as the vehicle or source of metaphor that is treated as if something that human always does. Further description of metaphor in BSu and Bsa will be explained below:

\section{Differences:}

The differences are on the vehicles of both languages, the tenor from the result translation of both translators are similar to the background of the phrase of each translation. The female translation uses the literal technique to translate the phrase of holding onto while the male translator uses variation technique, which is by changing the metaphor terminology into non-metaphorical without eliminating the meaning.

\section{Similarities:}

The translation of phrase holding onto by both translators is translated into a non-metaphorical phrase. The translation technique is also different. The variation technique used by the female translator creates similar tenor of $\mathrm{BSu}$ and $\mathrm{Bsa}$, it means this translation doesn't eliminate the metaphorical meaning from $\mathrm{BSu}$ vehicle although it is translated into nonmetaphorical terminology.

\author{
Analysis: \\ BSu: They did not ask for this adventure. (Speech D, ph 6) \\ Bsa1: Mereka_tidak_meminta_petualangan_ini. \\ Bsa2: Mereka_tidak_meminta_petualangan_ini.
}

The vehicle or source field is on the data 6 , which is an adventure, in categorized of structural metaphor due to the target field (life) tries to be explained by the structure from that source field. Since mostly there are challenges to face and long process in life, so this metaphor word of adventure with this background exists to explain life.

\section{Differences:}

There are differences between vehicle from $\mathrm{BSu}$ and $\mathrm{Bsa}$ since as mentioned before, both are the different languages. The background of BSu and Bsa metaphor is different as well, the background of $\mathrm{BSu}$ is the experience to challenge and courageous while the background of Bsa is the behavior.

\section{Similarities:}

The tenor of those three columns above has similarities, where the metaphor of $\mathrm{BSu}$ is translated into a metaphor of 
Bsa by using the common-matching technique. Although both languages have different vehicles, but the tenor keeps the same to state the metaphor of adventure or petualangan. Since the Bsa speaker also can easily understand the conceptual structure of petualangan as the metaphor of life.

\section{Analysis:}

BSu: We must seize the day. (Speech D, ph 35)

Bsa1: Kita harusmenangkaphariini.

Bsa2: Kita harus_memanfaatkan_waktu_ini_dengan_sebaikbaiknya.

The sentence on data 7 has the metaphor terminology on the word seizethat can be categorized as structural metaphorical. This definition is due to the background of the word seize takes or has something completely and the phrase of the day is the target field that is structurally concept the movements or space, so on this metaphor, time is a certain thing to have or use completely or well.

\section{Differences:}

Besides the differences on the vehicle from BSu and Bsa, on Bsa itself exists the differences. The metaphor of seize is translated using the literal technique into the words which are no metaphor while the female translation translates the metaphor into non-metaphorical terminology using the variation technique. Besides the difference between vehicle and technique, tenor and backgrounds of both Bsa are different as well. So, it can be concluded that the different technicals can create the different vehicle and tenor for metaphor or non-metaphor terminology.

\section{Similarities:}

There are similarities on the tenor of $\mathrm{BSu}$ and $\mathrm{Bsa}$ metaphor, which are the word seize is understood as an action to utilize the time well. For Bsa that is translated by the female translator to be non-metaphor to create the same background and tenor. The similarity between both translators is on the common-matching technique used to translate the phrase of the day, it is due to this terminology has had the resemblance word in Bsa.

\section{Analysis:}

BSu: We need to help America fall in love all over again... (Speech D, ph 41)

Bsa1: Kita harus_membantu Amerika jatuh_cinta_lagi...

Bsa2: Kita perlu_membantu Amerika jatuh_cinta_sekali_lagi...

The metaphor terminology on data number 8 shows the concrete concept of vehicle fall in to pronounce the abstract concept of love (cinta) as an entity that can be placed into anthology metaphor (container).

\section{Differences:}

Besides the differences on the vehicle that is caused by two different languages, the different also exists on the background aspect of the $\mathrm{BSu}$ metaphor and the Bsa background aspect.

\section{Similarities:}

The tenor aspect on $\mathrm{BSu}$ and $\mathrm{Bsa}$ has similarities, it perhaps happens due to both translators use commonmatching technique that is the terminology has been commonly used or can be easily understood by the Bsa speaker, and this technique doesn't change the metaphor into non-metaphor but into the metaphor terminology as well.

\section{Analysis:}

BSu: ... in the serene majesty of Killian Court... (Speech D, ph 46)

Bsa1: ... dalam_keaguangan_menentramkan_dari_Pengadilan Killian...

Bsa2: ... dalam_keaguangan_Killian Court yang tenang...

Data 8 is also categorized into the ontological metaphor (personification) due to the characteristic of glory and grandeur that is commonly used by human to describe a room/ place, it is probably mean to simplify the description of that place/ room.

\section{Differences:}

The differences exist in the vehicle between BSu and Bsa.

\section{Similarities:}

Tenor from $\mathrm{BSu}$ and Bsa has similarity, where the metaphor terminology of majesty has the grandeur and beautiful meaning to help to explain the concept of Killian Court as a target field. Furthermore, the translation for vehicle aspect and background of the metaphor is similar, it is caused by the similarity of translation technique used by both translators, which is the common-matching technique although structurally the phrase has a little more differences of the word order.

\section{Analysis:}

BSu: ... need to be the spark that ignites the passion of every child... (Speech D. Ph 47)

Bsa1: Kita harus_menjadi_percikan_yang menghidupkan semangat_dari_setiap_anak...

Bsa2: Kita perlu_menjadi_bunga_api_yang menyulut_gairah setiap_anak...

Data 10 is categorized into structural metaphor due to the concept of spark structurally can explain the target field of passion that is often paired with the field of fire source. Furthermore, the metaphor terminology of ignites is ontology metaphor (personification) since it gives the impression as the human's characteristic or ability to do something for the target field of spark.

\section{Differences:}

The word spark on BSu has different background compared by both translators, another difference lays on the 
vehicle aspect of metaphor, as previously, it is caused by both are different languages. The differences on the vehicle aspect on both Bsa also can be seen here although using the same technique, both translators choose different dictions to describe the message of spark and ignites.

\section{Similarities:}

The metaphor of spark is translated using Bsa metaphor by the same technique, which is the common-matching technique, due to both metaphors on Bsa have been understood and used in daily conversation by the Bsa speakers. The similarities or resemblance of $\mathrm{BSu}$ and $\mathrm{Bsa}$ metaphor exists on the tenor aspect from the three text above.

The speech text that has metaphor as the figure of speech is different to the text generally since mostly the listeners don't understand with the metaphor so it needs a special technique to translate, referring to the semantic theory. According to the analysis result that has been done, it has been found that the usage metaphor is interesting to be studied as there are the different results of the metaphor translations between two translators. In the context of speech text translation from the source language to the target language, the translators must be able to transfer the metaphor from the source language into the target language accurately, so it can be accepted and readable by the readers. That's why the translators need to have the linguistic competence, especially related to the understanding of good language style in both source language and target language.

The reality is sometimes the translator isn't able to transfer the message accurately, where the metaphor language style used in the source language isn't translated into the metaphor language of the target language, so the beauty of metaphor cannot be seen on the target language. That's why the translator must understand the types of metaphor both in the source and target language so the result will be accurate, acceptable and readable. In this case, the decision of the translator to choose certain translation technique is influenced by whether those translators understand a word or phrase which is a metaphor.

\section{CONCLUSION:-}

A translation needs the meaning agreement so a translator has to produce the accurate translation. The successful translation process will depend on how far a translator understands and wrestles the text area to be translated. To fulfill the good translation result, the translator has to be able to transfer the messages accurately. As well as the style of metaphor language used in the source language needs to be translated into the style of metaphor language in the target language, so the beauty of metaphor can be seen in the target language as well. That's why the translator needs to understand the semantic concept, types of good metaphor, both in source and target language so the result will be accurate, acceptable and readable. The translation texts that have been analyzed also show the perspective followed by the translator, especially while touching the culture and language source. The translator's decision to choose certain translation technique is influenced by some things, such as whether the translator understands a word or a phrase that is categorized as a metaphor.

\section{References}

Anastasia, T (2008). Analysis of metaphors used in Women College Presidents' inaugural addresses at Coed Institutions. Colorado: Colorado State University Fort Collins.

Baker, M. (2000). Towards a methodology for investigating the style of a literary translator. Target 12(2), 241-266.

Cruse, A - (2006). A glossary of Semantics and Pragmatics. Edinburgh: Edinburgh University Press.

Deignan, A. (2005). Metaphor and corpus linguistics. Amsterdam/Philadelphia.

Deignan, A. (2008). Corpus linguistics and metaphor.in Gibbs, R.W. (Ed.). The Cambridge handbook of metaphor and thought (h. 280-294). Cambridge: Cambridge University Press.

Deignan,A. (2010) The evaluative properties of metaphors.

Echols J.M. \& Shadily, H. (2003). Kamus Inggris-Indonesia (An English - Indonesian Dictionary). Jakarta: PT Gramedia Pustaka Utama.

Fawcett, P. (1997). Translation and language: Linguistic approaches explained. Manchester: St. Jerome.

Goatly, A. (1997).The language of metaphors. London: Routledge.

Hatim, B \& Mason, I. (1997). The translator as communicator. London: Routledge.

Hatim, B. (1997). Communication across cultures: Translation theory and contrastive text linguistics. Exeter: University of Exeter Press.

Hatim, B., \& Mason, I. (1990)._Discourse and translator. London: Longman.

Kamus_Besar Bahasa Indonesia. (2008). Jakarta: Gramedia Pustaka_Utama

Kittay, E. F. (1987). Metaphors: Its cognitive force and linguistic structure. Oxford: Oxford University Press.

Knowles, M.\& R. Moon (2005). Introducing metaphor. London: Routledge.

Knowles, M., \& Moon R. (2006). Introducing metaphor. London: Routledge. 
Koller, V. (2004).Metaphor and gender in business media discourse. New York: Palgrave Macmillan. Komunikasi .Jakarta .Salemba Humanika.

Kövecses, Z. (2002). Metaphor: A practical introduction. Oxford: Oxford University Press.

Kövecses, Z-(2000). The scope of metaphor. Barcelona, A.(Ed.)._-Metaphor and metonymy at the crossroads: A cognitive perspective (h. 79-92). Berlin: Mouton deGruyter.

Kridalaksana, H. (2008). Kamus_Linguistik. Jakarta: PT Gramedia_Pustaka_Utama.

Lakoff, G. (1993). The contemporary theory of metaphor.in Ortonoy, A. (Ed.). Metaphor and thought, 2nd edition. (h. 202-251). Cambridge: Cambridge University_Press.

Lakoff, G., \& Johnson, M. (2003).Metaphors we live by: With a new afterword. Chicago: University of Chicago Press.

Larson, M.L. (1984). Meaning-based translation: A guide to cross-language equivalence. London: University Press America,_Inc.

Larson, M.L. (1997). Meaning Based Translation 2nd Edition. New York: University Press of America.

Lee, D. (2001). Cognitive Linguistics: An introduction. Victoria: Oxford University Press. London: Routledge.

Moleong, L.J. (2008). Metodologi penelitian kualitatif. Jakarta: PT Remaja Rosdakarya.

Moleong, Lexy. J. (2010). Metodologi penelitian kualitatif. Bandung: Remaja Rosda Karya.

Molina, L \& Albir, A.H. (2002). "Translation techniques revisited: A dynamic and functionalist approach"Meta: Journal des Traducteurs/Meta: Translators' Journal. 47(4) 498-512

Nababan, M. R. (2004). Translation processes, practices and products of professional Indonesian translators. Unpublished Ph.D thesis. New Zealand: School of Linguistics and Applied Language_Studies.

Nababan, MR. (1997). Aspek teori penerjemahan dan pengalih bahasaan. Surakarta. UNS Press.

Newmark, P. (1982). Approaches to translation. Oxford: Pergamon

Newmark, P. (1988). A textbook of translation. London: Prentice Hall.

Nida \& Taber (1982) The theory and practice of translation. United States: Prentice Hall.

Ortony, A. (Ed.). (1979) Metaphor and thought, 2nd edition. (h. 202-251). Cambridge: Cambridge University Press.
Ritchie, D. (2013). Methapor. New York: Cambridge University Press.

Routledge Encyclopedia of Translation Studies. London: Routledge.

Saeed, J. I. (2000). Semantics._Oxford-:_Blackwell Publishers.

Shaw, A. H. (1915). The fundamental principle of a republic. Paper presented at the New York State Referendum, Albany, New York. Women Presidents' Speech Metaphors 92.

Steen, G. (2002). Towards a procedure for metaphor identification._Language and Literature,11_(1), 1733.

Strauss, A. L., \& Corbin, J. (1990). Basics of qualitative research: Grounded theory procedures and techniques. Newbury Park, CA: Sage.

Ullmann, S. (1962). Semantics: An Introduction to the Science of Meaning. Oxford:_Blackwell.

Ullmann, S. (1964). Semantics: an introduction to the science of meaning. Oxford:_Blackwell. 